\title{
Frequency and Cytokine Profile of HPRT Mutant T Cells in HIV-infected and Healthy Donors: Implications for T Cell Proliferation in HIV Disease
}

\author{
Carla Paganin, ${ }^{\star}$ Dimitrios S. Monos, ${ }^{\ddagger}$ Jason D. Marshall, ${ }^{\star}$ lan Frank, ${ }^{\S}$ and Giorgio Trinchieri ${ }^{\star}$ \\ *The Wistar Institute of Anatomy and Biology, ${ }^{\star}$ Department of Pathology and Laboratory Medicine, and ${ }^{\S}$ Department of Medicine, \\ University of Pennsylvania, Philadelphia, Pennsylvania 19104
}

\begin{abstract}
It has been postulated that HIV-infected patients undergo an active production of virus and $\mathrm{CD}^{+}{ }^{+} \mathrm{T}$ cell destruction from the early stages of the disease, and that an extensive postthymic expansion of $\mathrm{CD}^{+} \mathrm{T}$ cells prevents a precipitous decline in $\mathrm{CD4}^{+} \mathrm{T}$ cell number. Based on the rebound of the $\mathrm{CD}^{+} \mathrm{T}$ cell number observed in patients undergoing antiretroviral therapy with protease inhibitors, it has been calculated that, on average, $5 \%$ of $\mathrm{T}$ cells are replaced every day in HIV-infected patients. To obtain an independent estimate of the recycling rate of $T$ cells in the patients, we measured the frequency of cells carrying a loss-of-function mutation at the hypoxanthine guanine phosphoribosyl transferase (hprt) locus. Assuming a recycling rate of $5 \% / \mathrm{d}$, an accumulation of 2.6 mutations $/ 10^{6} / \mathrm{yr}$ over the physiological accumulation was predicted. Indeed, we observed an elevated frequency of HPRT mutants in the $\mathrm{CD}^{+} \mathrm{T}$ cells of most patients with $<300 \mathrm{CD}^{+} \mathrm{T}$ cells $/ \mathrm{mm}^{3}$ of blood and in the $\mathrm{CD}^{+} \mathrm{T}$ cells of most patients with $<200 \mathrm{CD}^{+} \mathrm{T}$ cells/ $\mathrm{mm}^{3}$, consistent with an elevated and protracted increased division rate in both subsets. However, in earlier stages of the disease the mutant frequency in both $\mathrm{CD}^{+}$and $\mathrm{CD8}^{+} \mathrm{T}$ cells was lower than in healthy controls. The cytokine production profile of most HPRT mutant $\mathrm{CD}^{+} \mathrm{T}$ cell clones from both healthy and HIV-infected patients was typical of T helper cells type 2 (high IL-4 and IL-10, low IFN- $\gamma$ ), whereas the cytokine production pattern of wild-type clones was heterogeneous. The cytokine profile of $\mathrm{CD8}^{+}$clones was indistinguishable between HPRT mutants and wild type. Our data provide evidence of increased $\mathrm{CD}^{+}$and $\mathrm{CD8}^{+} \mathrm{T}$ cell recycling in the HIV-infected patients. (J. Clin. Invest. 1997. 99:663-668.) Key words: HIV infection • T cell turnover $\bullet$ hprt locus mutation $\cdot$ cytokines $\bullet T$ cell clones
\end{abstract}

\section{Introduction}

Infection with HIV type 1 leads to a continuous decline in the number of circulating $\mathrm{CD} 4^{+} \mathrm{T}$ lymphocytes during the average period of 8-10 yr between the acute infection and AIDS (1). The pathogenesis of HIV type 1 infection is closely linked to

Address correspondence to Dr. Giorgio Trinchieri, The Wistar Institute, 3601 Spruce Street, Philadelphia, PA 19104. Phone: 215-8983992; FAX: 215-898-2357; E-mail: trinchieri@wista.wistar.upenn.edu

Received for publication 10 April 1996 and accepted in revised form 3 December 1996.

J. Clin. Invest.

(C) The American Society for Clinical Investigation, Inc.

0021-9738/97/02/0663/06 \$2.00

Volume 99, Number 4, February 1997, 663-668 the replication of the virus in vivo, and it is now clear that even the early asymptomatic stages of the disease are characterized by very active viral replication, especially in lymphoreticular tissues (2). Because HIV type 1 directly targets $\mathrm{CD}^{+}{ }^{+} \mathrm{T}$ cells, at least some of the decrease in $\mathrm{CD}^{+} \mathrm{T}$ cell number is presumably due to the direct viral cytopathic effect on the infected cells. However, in addition to direct viral infection, immunological mechanisms of destruction of $\mathrm{CD}^{+} \mathrm{T}$ cells have been postulated, including induction of $\mathrm{T}$ cell anergy and apoptosis or destruction by inflammatory or immune cells $(1,3)$. Destruction of the anatomical architecture of lymphoid organs, the thymus in pediatric AIDS, and lymphoreticular tissues in all patients, might also contribute to the decrease in $\mathrm{T}$ cell number (1). It has also been postulated that an altered reactivity and ability of $\mathrm{CD}^{+} \mathrm{T}$ cells to proliferate in patients may eventually lead to their decrease in number. Indeed, a deficient ability of $\mathrm{T}$ cells from $\mathrm{HIV}^{+}$patients to proliferate in response to recall antigens, alloantigens, or mitogens is observed at early stages of the disease, when the patients are asymptomatic and $\mathrm{CD}^{+} \mathrm{T}$ cell numbers are still within normal range $(4,5)$. This inability of $T$ cells to proliferate in vitro may not be due uniquely to an intrinsic defect of $T$ cells, but also to a deficiency in the antigen-presenting cells (APC) ${ }^{1}$ to which T cells are exposed in vivo and in vitro.

Numerous observations indicating activation of $\mathrm{T}$ cells at all phases of HIV disease challenge the notion that the destruction of a proportion of $\mathrm{CD}^{+}{ }^{+} \mathrm{T}$ cells in latent HIV infection is accompanied by a lack of reactivity and proliferation of $\mathrm{T}$ cells, resulting in decreased production and eventual decline of $\mathrm{CD}^{+} \mathrm{T}$ cells. Indeed, during the clinical latency period of $\mathrm{HIV}$ infection, there is a massive infection of $\mathrm{CD} 4^{+} \mathrm{T}$ cells and macrophages in lymph nodes, and a gradual disappearance of T cells with naive phenotype $\left(\mathrm{CD} 45 \mathrm{RA}^{+}, \mathrm{RO}^{-}\right)$, which are replaced largely by cells with a memory phenotype (CD45 $\mathrm{RA}^{-}$, $\left.\mathrm{RO}^{+}\right)(6,7)$. This suggests either a continuous proliferation in response to antigenic stimulation or an active postthymic $\mathrm{T}$ cell proliferation directed to maintain the $\mathrm{CD}^{+} \mathrm{T}$ cell number (7-9). Based on the rebound in $\mathrm{CD}^{+} \mathrm{T}$ cell number in response to anti-viral therapy with protease inhibitors, a rapid $\mathrm{CD}^{+} \mathrm{T}$ cell turnover has been demonstrated in HIV patients, with an average replacement of 5\%/d (10-12). However, the interpretation of these data has been challenged based on the possibility that most of the rebound $\mathrm{CD}^{+} \mathrm{T}$ cell number reflects increased recirculation from lymphoid tissues (13), thus overestimating the putative increased turnover of $\mathrm{CD}^{+} \mathrm{T}$ cells in HIV-infected patients.

A CD $4{ }^{+}$cell turnover of $5 \%$ per day represents a dramatic decrease in $\mathrm{CD}^{+} \mathrm{T}$ cell life span in patients compared with

1. Abbreviation used in this paper: hprt, hypoxanthine guanine phosphoribosyl transferase. 
healthy donors. Although some of the destroyed cells may be replaced through thymic production of newly generated $\mathrm{T}$ cells, it is likely that in adult HIV-infected patients the $\mathrm{CD}^{+}{ }^{+} \mathrm{T}$ cell replenishment is dependent mostly on postthymic $\mathrm{T}$ cell expansion. Thus, to prevent a precipitous drop in the number of $\mathrm{CD}^{+} \mathrm{T}$ cells, an increase in the average division rate of $\mathrm{CD}^{+}$ T cells to more than 19 divisions/yr is necessary to maintain a $5 \%$ turnover rate. One experimental approach to evaluate the number of divisions in vivo in the lymphocyte population is to analyze the frequency of somatic mutations accumulating in these cells (14). Of various possible loci that are subject to mutation and could be used for analysis, the X-linked hypoxanthine guanine phosphoribosyl transferase (hprt) locus represents an ideal choice for analysis of mutation in lymphocytes (14). Loss-of-function mutations in the hprt locus can be readily quantitated by evaluating the growth of clonal $\mathrm{T}$ cells in the presence of 6-thioguanine, which blocks the growth of the cells with a functional HPRT gene product $(14,15)$. The frequency of HPRT mutant $\mathrm{T}$ cells in peripheral blood increases linearly with age (from 0.5 to 10 mutants $/ 10^{6} \mathrm{~T}$ cells) reflecting the normal $\mathrm{T}$ cell turnover and regeneration, with an increase of approximately one mutant $/ 10^{6} \mathrm{~T}$ cells every $5 \mathrm{yr}$ (15). This increase, assuming no negative or positive selection for HPRT mutant cells, corresponds to a mutation rate of $8.4 \times 10^{-7}$ per cell division (15), based on an average $\mathrm{T}$ cell half-life of $3 \mathrm{yr}$ ( 0.26 divisions/yr). A negative selection for HPRT mutant cells probably plays a major role in T cell development in the bone marrow and thymus due to an increased requirement for the purine salvage pathway in these microenvironments, but most likely only a minimal role in postthymic $\mathrm{T}$ cell expansion, such as that mostly responsible for $\mathrm{T}$ cell replenishment in adults (16). In several autoimmune diseases, e.g., systemic lupus erythematosus, most patients show a dramatically increased number of HPRT mutant $\mathrm{T}$ cells, due to the chronic stimulation and proliferation of the autoreactive T cell subsets $(17,18)$, indicating that the mutant $T$ cells can accumulate in the patients without evidence of a significant negative selection to limit the expansion of the mutant clones. In this study, we tested whether the postulated increased CD $4^{+}$ $\mathrm{T}$ cell turnover in $\mathrm{HIV}(+)$ patients is reflected in an increased frequency of HPRT mutant T cells. If the T cell replacement in $\mathrm{HIV}(+)$ patients is on average 5\% (corresponding to 19 divisions/T cell/yr), an increase of HPRT mutants of $\sim 2.6 \mathrm{mu}-$ tants $/ 10^{6}$ CD4 T cells/yr was expected.

\section{Methods}

Reagents. Phytohemagglutinin (PHA) was purchased from GIBCO BRL (Gaithersburg, MD). 12-0-tetradecanoyl-phorbol-13-acetate (TPA) was from Sigma Chemical Co. (St. Louis, MO). Anti-CD3, anti-CD4, and anti-CD8 mAb produced from cells were obtained from American Type Culture Collection (Rockville, MD). Human recombinant IL-2 (rIL-2) was a gift of Dr. T. Taguchi (Osaka University, Osaka, Japan).

Subjects. Peripheral blood mononuclear cells (PBMC) were obtained by Ficoll-Hypaque gradient separation from peripheral blood of healthy volunteers and HIV type 1-infected individuals, recruited from the Immunodeficiency Program of the Hospital of the University of Pennsylvania. CD4 ${ }^{+}$lymphocyte counts were obtained on the same day that the patients' blood was obtained for use in this study. Patients were categorized according to the Centers for Disease Control criteria on the basis of $\mathrm{CD}^{+}$lymphocyte number and HIVrelated symptomatology and complications (19).
Generation of $\mathrm{CD}^{+}$and $\mathrm{CD}^{+} \mathrm{T}$ cell clones. $\mathrm{T}$ cell clones were generated from PBMC by limiting dilution $(20,21)$. To determine clonal efficiency in nonselective medium and to generate wild-type clones, 1.0 and $0.5 \mathrm{PBMC} /$ well were seeded in 96-well round bottom tissue culture plates in $200 \mu \mathrm{l}$ of RPMI-1640 medium with $10 \%$ FCS in the presence of $5 \mu \mathrm{g} / \mathrm{ml}$ PHA, $\gamma$-irradiated (50 Gy) allogeneic PBMC $\left(3 \times 10^{4}\right.$ cells/well $)$ and RPMI-8866 B lymphoblastoid cells ( $10^{4}$ cells/well). To expand HPRT mutants, $2 \times 10^{4} \mathrm{PBMC} /$ wells were seeded in 96-well round bottom tissue culture plates in $200 \mu \mathrm{l}$ RPMI1640 medium with $10 \%$ FCS and 6-thioguanine (2 amino-mercaptopurine, $10^{-5} \mathrm{M}$; Sigma Chemical Co.), in the presence of $5 \mu \mathrm{g} / \mathrm{ml}$ PHA, $\gamma$-irradiated allogeneic PBMC (104/well) and RPMI-8866 cells (10/well). After $40 \mathrm{~h}, \mathrm{IL}-2$ (50 U/ml, final concentration) was added to all cultures by replenishing half of the medium. After $1 \mathrm{wk}$, irradiated PBMC $\left(5 \times 10^{3} /\right.$ well $)$ and RPMI-8866 $\left(10^{4} /\right.$ well $)$ as feeder cells were added again; cells were maintained in culture with IL-2 and fed and split as required with the original selective or nonselective medium maintained through the culture period. Cloning efficiency was calculated for $\mathrm{CD}^{+}$or $\mathrm{CD}^{+}$by Poisson distribution as described in references 20-22; only wells containing a sufficient $\mathrm{T}$ cell number to allow determination of both surface phenotype and cytokine profile were considered positive. The proportion of $\mathrm{CD}^{+}$and $\mathrm{CD}^{+} \mathrm{T}$ cells in the plated PBMC was taken into account in calculating the number of cells from either subset plated per well. The mutant frequency $(\mathrm{mF})$ of $\mathrm{T}$ cells was determined as the ratio of the cloning efficiency in selective and nonselective medium $(15,23) ; 95 \%$ confidence limits were calculated using Poisson distribution tables.

Surface phenotype of T cells. The phenotype of PBMC and T cell clones was examined by immunofluorescence (flow cytometry) using FITC-conjugated anti-CD3, anti-CD4, and anti-CD8 mAbs as described in reference 21.

Induction of cytokine production by T cell clones. To induce cytokine production, $\mathrm{T}$ cell clones were resuspended in complete medium to a concentration of $\sim 10^{6} / \mathrm{ml}$ and stimulated for $24 \mathrm{~h}$ with soluble anti-CD3 mAb (OKT3, ascites 1:10,000) and TPA (10 ng/ml). Cell free culture supernatants were collected and stored in aliquots at $-70^{\circ} \mathrm{C}$ until used.

Quantitation of $I F N-\gamma, I L-4$, and $I L-10$. IFN- $\gamma$ was quantitated in $\mathrm{T}$ cell clone supernatants by radioimmunoassay (RIA) using mAbs B133.1 and B133.5 (24); IL-4 was quantitated by RIA using antibodies 4F2 and 5A4 (25), gift of Dr. Lucien Aarden (Central Laboratory of the Netherlands Red Cross, Amsterdam, The Netherlands); IL-10 was quantitated by RIA using antibodies JE53, 9D7, and 12G8, gift of Dr. Anne O'Garra (DNAX, Palo Alto, CA). Recombinant human IFN- $\gamma$, IL-4, and IL-10 were used as reference standards.

\section{Results}

$18 \mathrm{HIV}(+)$ patients were analyzed $\left[\mathrm{CD}^{+} \mathrm{T}\right.$ cells $/ \mathrm{mm}^{3}$ ranging from 660 to 0 , age (mean \pm SE) 34.7 \pm 1.3 yr (24-44 range), 14 males and 4 females] and compared with 10 healthy HIV $(-)$ controls [age $35.4 \pm 3.3$ yr (24-57 range), 2 males and 8 females]. The cloning efficiency in nonselective medium was comparable in the two groups $\left[\mathrm{HIV}(+)\right.$ donors: $\mathrm{CD}^{+}$ clones, 0.65 $\pm 0.04 ; \mathrm{CD}^{+}$clones, 0.52 $\pm 0.05 ; \mathrm{CD}^{+}$clones, 0.66 \pm 0.05 ; $\mathrm{HIV}(-)$ donors: $\mathrm{CD}^{+}$clones, 0.59 \pm 0.07 ; $\mathrm{CD}^{+}$ clones, $0.65 \pm 0.08 ; \mathrm{CD}^{+}$clones, $\left.0.37 \pm 0.10\right]$. No obvious change in cloning efficiency was observed with disease progression, except for a lower efficiency in $\mathrm{CD}^{+} \mathrm{T}$ cells in the four patients with $<100 \mathrm{CD}^{+} \mathrm{T}$ cells $/ \mathrm{mm}^{3}$. The frequency in HIV $(-)$ control donors of HPRT mutant cells expanded in the 6-thioguanine was similar to that previously reported $(15,23)$ for this age range $\left[\mathrm{CD}^{+}\right.$cells, $9.9 \pm 1.1$ mutants $/ 10^{6}$ cells; $\mathrm{CD}^{+}$cells, 11.9 \pm 1.6 ; $^{-C D^{+}}$cells, $7.4 \pm 2.3$ ]. As shown in Fig. 1, the mutant frequency in patients with elevated numbers of $\mathrm{CD}^{+} \mathrm{T}$ cells is similar to or lower than that of healthy donors; however, at 


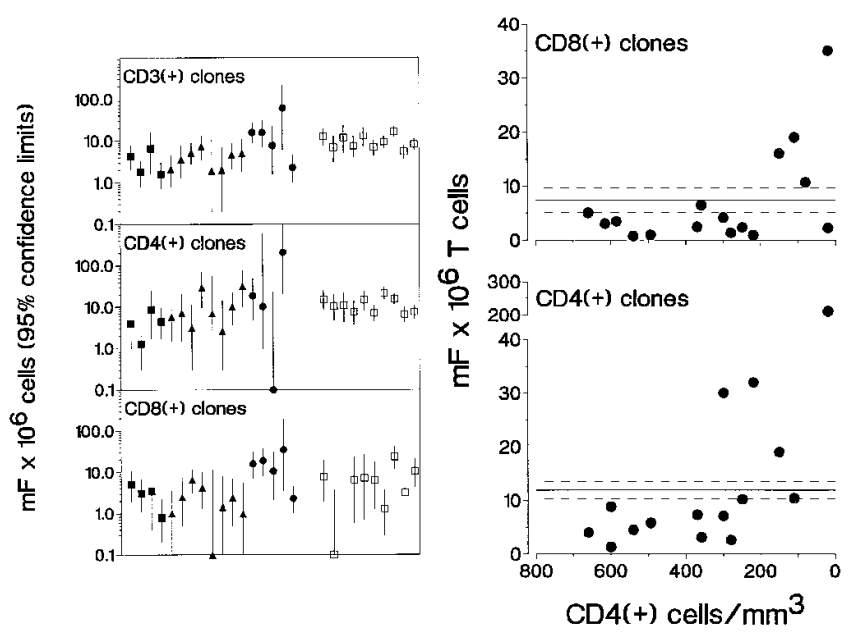

Figure 1. HPRT mutant frequency $(m F)$ in T cells from HIV-infected and healthy donors. The left panel shows the determined HPRT mutant frequency and $95 \%$ confidence limits in total $\mathrm{CD}^{+} \mathrm{T}$ cells and in $\mathrm{CD}^{+}$and $\mathrm{CD}^{+} \mathrm{T}$ cell subsets in HIV-infected patients $(\mathbf{\square},>500$ $\mathrm{CD}^{+}{ }^{+} \mathrm{T}$ cells $\left./ \mathrm{mm}^{3} ; \boldsymbol{\Lambda}, 200-500 ; \boldsymbol{\bullet},<200\right)$ and in healthy blood donors $(\square)$. The right panel shows the mutant frequency in $\mathrm{CD}^{+}$and $\mathrm{CD}^{+} \mathrm{T}$ cells from HIV-infected patients plotted against the number of $\mathrm{CD}^{+} \mathrm{T}$ cells $/ \mathrm{mm}^{3}$ of blood at the time samples were obtained. The zero values from the patients from which no HPRT mutant clones were isolated are not reported in the right panel. The continuous and broken horizontal lines indicate the average frequency \pm 1 S.E. of HPRT mutant $T$ cells in healthy donors.

later stages of the disease, with low $\mathrm{CD}^{+} \mathrm{T}$ cell numbers, an increase in mutant frequency was observed in most patients. An increased mutant frequency in $\mathrm{CD}^{+}$cells was observed in most patients with $<300 \mathrm{CD}^{+}$cells $/ \mathrm{mm}^{3}$ (comparison of mutant frequency between patients with more or $<300 \mathrm{CD}^{+} \mathrm{T}$ cells, $t=1.84, P=0.044$ ) and in $\mathrm{CD}^{+}$cells in patients with $<200 \mathrm{CD}^{+}$cells $/ \mathrm{mm}^{3}(t=3.8, P=0.001)$. Regression analysis shows that for both $\mathrm{CD}^{+}$and $\mathrm{CD}^{+} \mathrm{T}$ cell clones, the mutant frequency was inversely proportional to the number of $\mathrm{CD}^{+}$ T cells $\left(\mathrm{CD}^{+}\right.$clones: $\mathrm{F}=5.5, P=0.035 ; \mathrm{CD}^{+}$clones, $\mathrm{F}=$ 5.98, $P=0.028)$. Because of the low number of $\mathrm{CD}^{+} \mathrm{T}$ cells available for analysis, mutant $\mathrm{CD}^{+} \mathrm{T}$ cell clones were isolated only in one out of three patients with $<100 \mathrm{CD}^{+}$ $\mathrm{T}$ cells $/ \mathrm{mm}^{3}$.

The pattern of cytokine production was analyzed in clones expanded for 4-5 wk and stimulated for $24 \mathrm{~h}$ with soluble antiCD3 antibodies and phorbol diester; Fig. 2 shows production of cytokines from individual $\mathrm{CD}^{+}$clones from healthy patients, and Fig. 3 shows average cytokine production for all clones. The wild-type $\mathrm{CD} 4^{+}$clones expanded in the absence of 6-thioguanine produced heterogeneous levels of IFN- $\gamma$, IL-4, and IL-10, without clearly identifiable Th1 or Th2 patterns. The wild-type $\mathrm{CD}^{+}$clones from $\mathrm{HIV}(+)$ patients produced similar levels of IFN- $\gamma$ and IL-4 and approximately twofold higher levels of IL-10 ( $P=0.0024$, Student's $t$-test $)$ than those from healthy donors. The HPRT mutant $\mathrm{CD}^{+}$clones from healthy donors expanded in the presence of 6-thioguanine produced significantly less IFN- $\gamma(P=0.0009)$ and more IL-4 $(P<0.0001)$ and IL-10 $(P<0.0001)$ than the wild-type $\mathrm{CD}^{+}$ clones. Similarly, HPRT mutant clones from HIV $(+)$ patients produced significantly less IFN- $\gamma(P=0.0152)$ and more IL-4

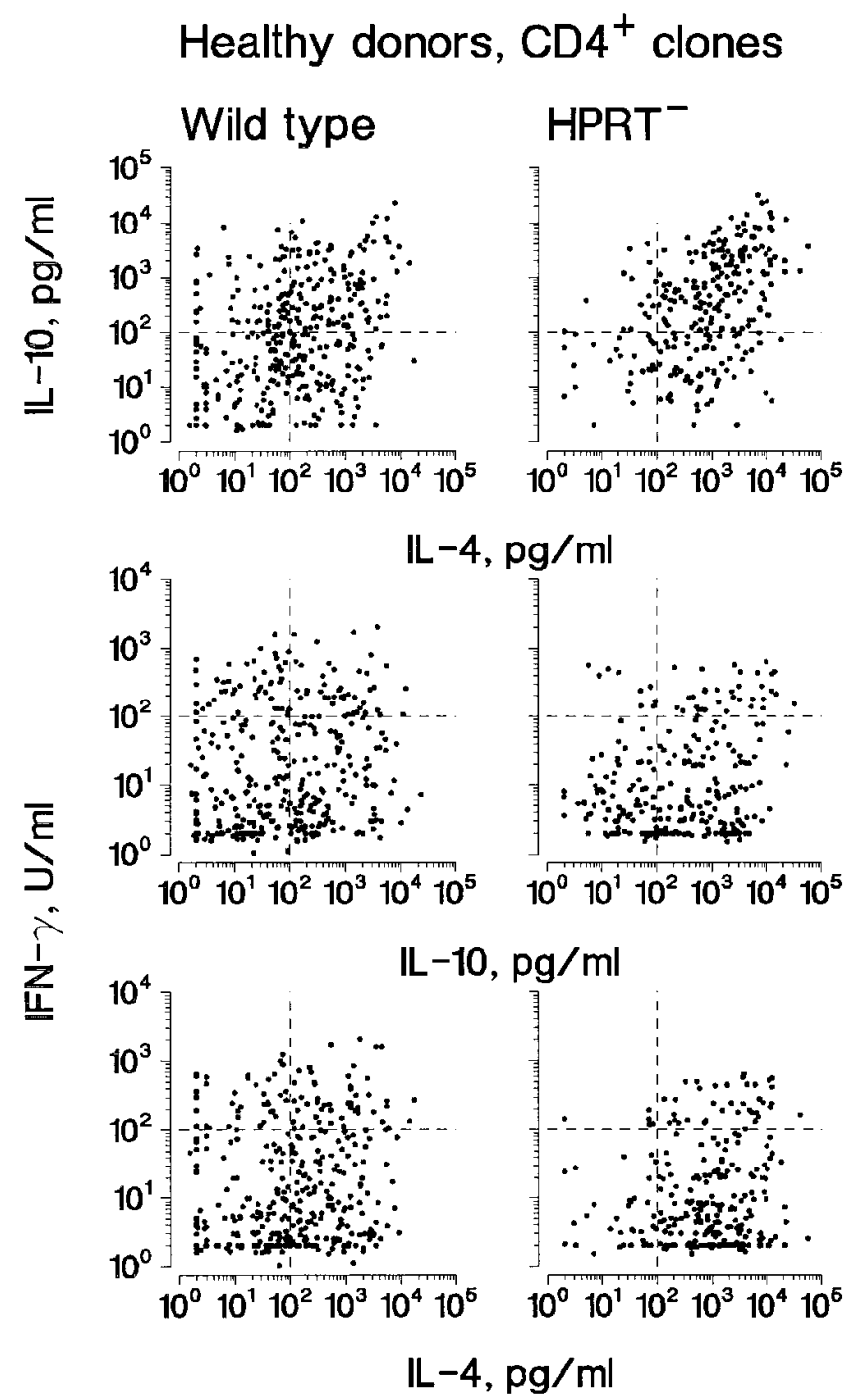

Figure 2. Cytokine production of wild-type or HPRT mutant CD4 $4^{+}$ $\mathrm{T}$ cell clones from HIV-negative healthy blood donors. T cell clones were expanded for four to five weeks; production of IFN- $\gamma$, IL-4 and IL-10 was determined by radioimmunoassay in the cell free supernatant fluid of the clones stimulated for $24 \mathrm{~h}$ with soluble antiCD3 antibodies and phorbol diester. Each dot represents an individual clone; clones from 10 different blood donors are shown.

$(P<0.0001)$ than wild-type clones. Thus, the majority of HPRT mutant $\mathrm{CD} 4^{+}$clones, both from healthy controls and patients produced low IFN- $\gamma$ and high IL-4 and IL-10, a cytokine pattern typical of Th2 cells.

The $\mathrm{CD}^{+} \mathrm{T}$ cell clones from the HIV $(+)$ patient produced higher levels of IFN- $\gamma(P<0.0001)$ than those derived from the healthy donors (Fig. 3). This increase in average production of IFN- $\gamma$ was due to an increase in the proportion of IFN- $\gamma-$ producing $\mathrm{CD}^{+}$clones derived from healthy donors (not shown), suggesting that these results may reflect the presence of the peripheral blood of $\mathrm{HIV}(+)$ patients of a higher proportion of activated/memory $\mathrm{CD}^{+}$cells primed for high production of IFN- $\gamma$. Unlike $\mathrm{CD}^{+} \mathrm{T}$ cells, most $\mathrm{CD}^{+}$clones produced IFN- $\gamma$ and only low levels of the Th2-type cytokines IL-4 and IL-10; the cytokine profile of HPRT mutant $\mathrm{CD}^{+} \mathrm{T}$ cell 


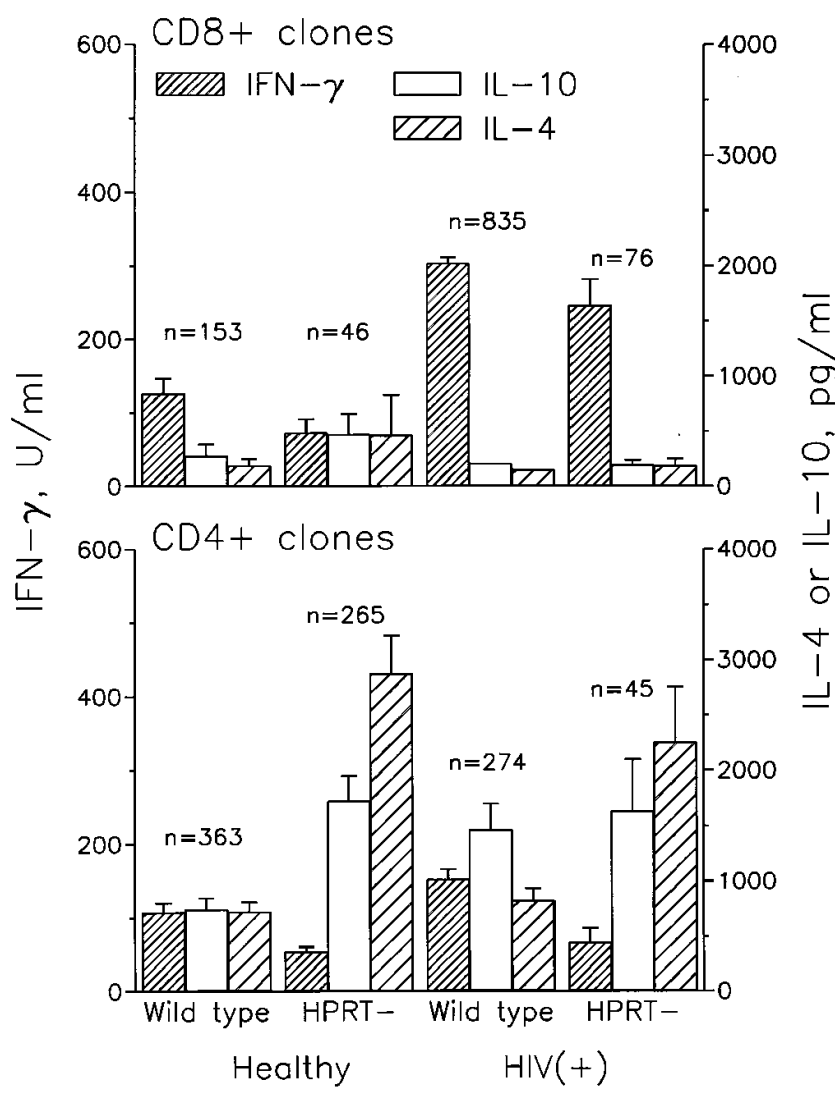

Figure 3. Cytokine production by $\mathrm{CD} 4^{+}$and $\mathrm{CD} 8^{+} \mathrm{T}$ cell clones (wild-type or HPRT mutant) derived from HIV-infected patients or healthy donors. The columns and error bars indicate the average cytokine production + S.E. by the indicated number of clones, derived from a total of $18 \mathrm{HIV}$-infected patients and 10 healthy blood donors.

clones from both healthy donors and $\mathrm{HIV}(+)$ patients did not differ significantly from that of wild-type clones.

\section{Discussion}

An evident increase in HPRT mutant frequency, well above that of healthy controls, was observed for $\mathrm{CD} 4^{+} \mathrm{T}$ cells in most patients with $<300 \mathrm{CD} 4^{+} \mathrm{T}$ cells $/ \mathrm{mm}^{3}$ and for $\mathrm{CD} 8^{+} \mathrm{T}$ cells in patients with $<200 \mathrm{CD}^{+} \mathrm{T}$ cells $/ \mathrm{mm}^{3}$. Unfortunately, the lack of a sufficient number of $\mathrm{CD}^{+} \mathrm{T}$ cells available for analysis prevented determination of whether the mutant frequency increased further in the terminal stages of the disease $[<100$ $\mathrm{CD}^{+} \mathrm{T}$ cells $\left./ \mathrm{mm}^{3}\right]$. Although the precise date of infection is not known for all the patients studied, the available information on some of the patients suggests that the increased mutant frequency is a function of $\mathrm{CD}^{+}$cell number rather than duration of the disease. These data support an increased division rate of $\mathrm{CD}^{+}{ }^{+} \mathrm{T}$ cells in HIV disease. However, the HPRT mutant $\mathrm{T}$ cell frequency in the $\mathrm{HIV}(+)$ patients until the number of $\mathrm{CD}^{+}$reached levels $<300 / \mathrm{mm}^{3}$ was not higher than in healthy donors of equivalent age, but actually lower, although many of these patients have been diagnosed or are otherwise known to have been infected with HIV for more than five years, thus predicting a theoretical average accumulation of HPRT mutant $T$ cells at least 13 mutants $/ 10^{6}$ cells higher than that of healthy controls. The observed lower mutant frequency than in healthy controls might reflect the absence of any marked increase in $\mathrm{T}$ cell recycling in the early phases of the disease and/or negative selection of HPRT mutant cells in the patients. A negative selection in vitro due to the presence of infectious HIV in the cultures is unlikely, because experiments in which HPRT mutant frequency was determined in a mixture of PBMC from $\mathrm{HIV}^{+}$and $\mathrm{HIV}^{-}$donors, no inhibitory effect on the growth of the mutant clones was observed (not shown). Because HIV preferentially replicates in and destroys activated/dividing $\mathrm{T}$ cells, and because the HPRT mutation frequency is a function of $\mathrm{T}$ cell divisions, one could argue that the mutant cells are preferentially destroyed by the virus infection. However, because there is no a priori reason to assume that the virus may preferentially infect the mutant cells compared to other proliferating $\mathrm{T}$ cells, the relative accumulation of mutations in the surviving cells should not be affected by the continuous elimination and replenishment of $T$ cells during the infection. Another possible explanation may be suggested by the Th2-type cytokine profile of the mutant cells which suggests that the mutation tends to accumulate in a memory $T$ cell subset with particular characteristics. The typical Th2 phenotype of the mutant $\mathrm{CD} 4^{+} \mathrm{T}$ cells was an unexpected finding, suggesting that, on average, memory Th2 cells undergo a much higher number of cell divisions than other Th subsets. This could be a general characteristic of Th2 memory cells or reflect the chronic stimulation of Th2 cells by environmental allergens, unlike the rarer occurrence of stimulation of Th1 cells by infection or other antigens inducing this Th subset. Interestingly, this shift to a Th2 phenotype in the mutant $\mathrm{CD} 4^{+} \mathrm{T}$ cell clones was observed in all healthy and $\operatorname{HIV}(+)$ donors tested, indicating that it was not a characteristic limited to a few atopic donors. Because Th2-type $\mathrm{CD}^{+}$clones have been described to be more permissive than the Th1-type clones for HIV replication (26), it is possible that the $\mathrm{CD}^{+} \mathrm{T}$ cell subset containing the HPRT mutant cells is more susceptible to HIV infection and thus that the accumulation of HPRT mutant clones is negatively regulated in infected individuals. This possibility could explain why the number of mutant cells is not increased, but rather decreased in the patients at an early stage of the disease. Unlike $\mathrm{CD} 4^{+} \mathrm{T}$ cells, no different cytokine production pattern was identified between wild-type and HPRT mutant CD8 ${ }^{+}$ $\mathrm{T}$ cell clones.

The increase in mutant frequency in $\mathrm{CD} 8^{+}$cells during somewhat more advanced stages of disease than those in which increased frequency was observed in $\mathrm{CD}^{+} \mathrm{T}$ cells suggests that $\mathrm{T}$ cell turnover is also increased in $\mathrm{CD} 8^{+} \mathrm{T}$ cells at a late stage of disease. The increased $\mathrm{CD}^{+} \mathrm{T}$ cell turnover may represent a compensatory mechanism to a bystander destruction of $\mathrm{CD} 8^{+} \mathrm{T}$ cells, which were indeed depleted in most patients with high $\mathrm{CD}^{+} \mathrm{T}$ cell mutant frequency, and/or a reactive expansion of $\mathrm{CD}^{+} \mathrm{T}$ cells in response to the HIV infection or to opportunistic infections (27). Analysis of the possible antigen specificity, clonality, and functions of the $\mathrm{CD} 4^{+}$ and $\mathrm{CD} 8^{+}$HPRT mutant clones will help to discriminate between these alternatives.

Although our study identified a marked difference in the cytokine production pattern between wild-type and HPRT mutant clones of both healthy and $\mathrm{HIV}(+)$ patients, relatively small differences were observed between $\mathrm{T}$ cell clones from controls and patients. A statistically significant increase of only approximately twofold was observed for IL-10 production in 


\begin{tabular}{|c|c|c|c|c|c|c|c|c|c|c|c|c|c|c|}
\hline \multirow[b]{3}{*}{ Donors } & \multirow[b]{3}{*}{ Age } & \multirow[b]{3}{*}{ Sex } & \multirow[b]{3}{*}{$\mathrm{CDC}$} & \multirow[b]{3}{*}{ CD4 no. } & \multirow[b]{3}{*}{ CD8 no. } & \multirow[b]{3}{*}{ Therapy } & \multicolumn{4}{|c|}{ CD4 clones } & \multicolumn{4}{|c|}{ CD8 clones } \\
\hline & & & & & & & \multicolumn{2}{|c|}{ Wild type } & \multicolumn{2}{|c|}{ HPRT(-) } & \multicolumn{2}{|c|}{ Wild type } & \multicolumn{2}{|c|}{ HPRT(-) } \\
\hline & & & & & & & No. clones & $\mathrm{CE}$ & No. clones & $\mathrm{MF} \times 10^{-6}$ & No. clones & $\mathrm{CE}$ & No. clones & $\mathrm{MF} \times 10^{-6}$ \\
\hline D16 & 24 & $\mathrm{~F}$ & HIV (-) & N.D. & N.D. & N.A. & 22 & 0.71 & 20 & 7.3 & 4 & 0.22 & 3 & 6.3 \\
\hline D22 & 24 & $\mathrm{M}$ & HIV $(-)$ & N.D. & N.D. & N.A. & 40 & 0.69 & 51 & 15.9 & 6 & 0.22 & 11 & 23.6 \\
\hline D14 & 25 & $\mathrm{~F}$ & HIV $(-)$ & N.D. & N.D. & N.A. & 22 & 0.23 & 11 & 7.8 & 5 & 0.05 & 2 & 6.4 \\
\hline D13 & 30 & $\mathrm{~F}$ & HIV(-) & N.D. & N.D. & N.A. & 10 & 0.99 & 7 & 11.0 & 0 & N.D. & 1 & N.D. \\
\hline D15 & 33 & $\mathrm{~F}$ & HIV $(-)$ & N.D. & N.D. & N.A. & 11 & 0.36 & 15 & 15.0 & 3 & 0.18 & 2 & 7.2 \\
\hline D23 & 35 & $\mathrm{M}$ & HIV (-) & N.D. & N.D. & N.A. & 45 & 0.76 & 23 & 6.7 & 20 & 0.63 & 5 & 3.2 \\
\hline D12 & 40 & $\mathrm{~F}$ & HIV $(-)$ & N.D. & N.D. & N.A. & 30 & 0.81 & 9 & 10.5 & 11 & 0.55 & 0 & N.D. \\
\hline D11 & 43 & $\mathrm{~F}$ & HIV $(-)$ & N.D. & N.D. & N.A. & 12 & 0.85 & 15 & 15.3 & 7 & 0.80 & 4 & 7.6 \\
\hline D24 & 43 & $\mathrm{~F}$ & HIV $(-)$ & N.D. & N.D. & N.A. & 40 & 0.70 & 30 & 7.8 & 7 & 0.17 & 7 & 10.6 \\
\hline D17 & 57 & $\mathrm{M}$ & HIV(-) & N.D. & N.D. & N.A. & 28 & 0.42 & 34 & 21.7 & 37 & 0.89 & 3 & 1.3 \\
\hline P16 & 27 & $\mathrm{M}$ & $1 \mathrm{~A}$ & 600 & 1,020 & AZT/PRINH & 44 & 0.29 & 3 & 1.3 & 37 & 0.24 & 6 & 3.1 \\
\hline P19 & 29 & $\mathrm{~F}$ & $1 \mathrm{~A}$ & 600 & 840 & & 24 & 0.73 & 3 & 8.8 & 23 & 0.58 & 1 & 3.5 \\
\hline $\mathrm{P} 25$ & 36 & $\mathrm{~F}$ & $1 \mathrm{~A}$ & 540 & 1,770 & $\mathrm{AZT}$ & 30 & 0.60 & 6 & 4.5 & 82 & 0.63 & 3 & 0.8 \\
\hline $\mathrm{P} 26$ & 40 & $\mathrm{M}$ & $1 \mathrm{~A}$ & 660 & 1,180 & $\mathrm{AZT}$ & 32 & 0.40 & 4 & 4.0 & 38 & 0.70 & 6 & 5.1 \\
\hline P11 & 37 & $\mathrm{M}$ & $2 \mathrm{~A}$ & 370 & 1,470 & & 13 & 0.41 & 3 & 7.3 & 37 & 0.59 & 3 & 2.5 \\
\hline P17 & 36 & $\mathrm{M}$ & $2 \mathrm{~A}$ & 300 & 600 & AZT/PRINH & 6 & 0.14 & 5 & 30.0 & 38 & 0.55 & 5 & 4.2 \\
\hline P18 & 24 & $\mathrm{M}$ & $2 \mathrm{~A}$ & 300 & 1,230 & DDI & 10 & 0.55 & 1 & 7.1 & 29 & 0.92 & 0 & N.D. \\
\hline $\mathrm{P} 21$ & 28 & $\mathrm{M}$ & $2 \mathrm{~A}$ & 359 & 733 & AZT & 31 & 0.52 & 2 & 3.1 & 83 & 0.84 & 11 & 6.5 \\
\hline $\mathrm{P} 27$ & 41 & $\mathrm{M}$ & $2 \mathrm{~A}$ & 280 & 710 & AZT/DDI & 25 & 0.68 & 1 & 2.6 & 38 & 0.45 & 1 & 1.4 \\
\hline $\mathrm{P} 22$ & 31 & $\mathrm{M}$ & $2 \mathrm{~B}$ & 494 & 1,635 & AZT/PRINH & 15 & 0.74 & 4 & 5.8 & 41 & 0.73 & 2 & 1.0 \\
\hline $\mathrm{P} 28$ & 44 & $\mathrm{M}$ & $2 \mathrm{~B}$ & 250 & 720 & D4T & 29 & 0.61 & 6 & 10.2 & 51 & 0.71 & 3 & 2.4 \\
\hline $\mathrm{P} 14$ & 39 & $\mathrm{~F}$ & $2 \mathrm{C}$ & 220 & 800 & $\mathrm{AZT}$ & 7 & 0.73 & 5 & 32.0 & 44 & 0.73 & 1 & 1.0 \\
\hline P13 & 31 & $\mathrm{M}$ & $3 \mathrm{~A}$ & 110 & 320 & $\mathrm{AZT}$ & 5 & 0.52 & 1 & 10.4 & 29 & 1.00 & 8 & 19.0 \\
\hline $\mathrm{P} 15$ & 39 & $\mathrm{M}$ & $3 \mathrm{~B}$ & 150 & 790 & $\mathrm{D} 4 \mathrm{~T}$ & 26 & 0.62 & 4 & 19.0 & 64 & 0.35 & 9 & 16.0 \\
\hline $\mathrm{P} 12$ & 40 & $\mathrm{~F}$ & $3 C$ & 20 & 370 & D4T & 1 & 0.26 & 1 & 211.0 & 6 & 0.26 & 1 & 35.0 \\
\hline $\mathrm{P} 20$ & 30 & $\mathrm{M}$ & $3 \mathrm{C}$ & 20 & 880 & & 2 & 0.24 & 0 & N.D. & 121 & 0.82 & 8 & 2.3 \\
\hline $\mathrm{P} 23$ & 39 & $\mathrm{M}$ & $3 C$ & 80 & 390 & AZT/DDI & 3 & 0.31 & 0 & N.D. & 121 & 0.82 & 3 & 10.7 \\
\hline $\mathrm{P} 24$ & 34 & $\mathrm{M}$ & $3 C$ & 0 & 70 & D4T & 1 & 1.00 & 0 & N.D. & 20 & 0.95 & 0 & N.D. \\
\hline
\end{tabular}

PBMC from 10 healthy donors (D) and $18 \mathrm{HIV}$-infected patients $(P)$ were cloned under selective or nonselective conditions, as indicated in the text. The patients are listed according to the CDC classification. N.D., not determined; N.A., not applicable; PRINH, protease inhibitors; $C E$, cloning efficiency; $M F$, mutant frequency.

$\mathrm{CD}^{+}$clones from the patients compared to clones from healthy controls as well as an increase in IFN- $\gamma$ production in $\mathrm{CD}^{+} \mathrm{T}$ cell clones, possibly reflecting an increased proportion of activated/memory $\mathrm{CD}^{+} \mathrm{T}$ cells in peripheral blood (7). Our findings are consistent with those of other studies using polyclonal stimulation of total peripheral blood $\mathrm{T}$ cells (26) and may not reflect the cytokine profile of antigen-specific clones in the patients.

Overall, our analysis of HPRT mutant T cell accumulation in $\operatorname{HIV}(+)$ patients supports the previous conclusion $(11,12)$, based on the analysis of the $T$ cell number rebound after antiviral therapy, that there is an increased recycling (faster division rate) in the $\mathrm{CD}^{+} \mathrm{T}$ cells of the patients and shows that, at least at late stages of the disease, an increased recycling also takes place in $\mathrm{CD}^{+} \mathrm{T}$ cells. The increased accumulation of mutant $\mathrm{T}$ cells is observed at late rather than earlier stages of disease and depends more on the $\mathrm{CD}^{+} \mathrm{T}$ cell deficiency rather than on duration of disease and infection. The fact that an increased mutant frequency is observed only at a late stage of the disease may rest in the time needed for accumulation of the mutants, particularly given the possibility that a negative selective pressure is effective on the T cell subsets that comprise the mutant $\mathrm{T}$ cells in infected patients. However, the rate of $\mathrm{CD}^{+} \mathrm{T}$ cell expansion in the group of patients with low $\mathrm{CD}^{+} \mathrm{T}$ cell number may be higher than in the patients with high counts and could outpace any negative selection that may take place. Indeed, the combined present observation of the correlation of high mutant frequency with low $\mathrm{CD} 4^{+}$number and the previous observation of an increased rate of $\mathrm{CD}^{+} \mathrm{T}$ cells recovery in protease inhibitor-treated patients with low number of circulating $\mathrm{CD}^{+}$cells (12) suggest that an acceleration of $\mathrm{CD}^{+} \mathrm{T}$ cell turnover occurs in advanced disease.

Assay of the $\mathrm{T}$ cell mutant frequency in a large number of patients and a correlation with virus load will help to determine whether in some patients increased $\mathrm{T}$ cell proliferation maintains an elevated $\mathrm{T}$ cell number in the presence of active virus replication. However, the fact that the accumulation of HPRT mutant $T$ cells, even when associated with a major loss in $\mathrm{CD} 4^{+} \mathrm{T}$ cell number, is not as extensive as that observed in the case of chronic $\mathrm{T}$ cell stimulation in autoimmune diseases $(17,23)$, suggests that the failure to control the homeostasis of $\mathrm{CD} 4^{+}$cell number in the patients may not be due completely 
to exhaustion of the ability to replenish their number with continuous postthymic $\mathrm{T}$ cell expansion, but possibly also due to a defect in the ability of T cells to expand. The failure to produce a sufficient number of $T$ cells may depend on destruction of adult thymus remnants and lymphoreticular tissues, alteration in the cytokine milieu necessary for extrathymic T cell expansion, and/or altered antigen-presenting cell functions. To use the analogy proposed by Ho et al. (12), the sink empties not only because the drain is open ( $\mathrm{CD}^{+} \mathrm{T}$ cell destruction), but possibly also because the tap (lymphocyte production) is damaged and is inadequate to maintain the homeostatic level. Thus, it is important to continue the study of these mechanisms of defective $\mathrm{T}$ cell homeostasis in the patient and to determine whether therapeutic approaches to both improve lymphocyte regeneration and to block lymphocyte destruction are appropriate.

\section{Acknowledgments}

We thank Ms. Marion Kaplan for typing the manuscript.

This work was supported in part by United States Public Health Service grants CA10815, CA20833, CA32898, and AI34412, and by a contribution for AIDS research from the Commonwealth of Pennsylvania. C. Paganin is a recipient of fellowships from the Istituto Superiore di Sanitá (Rome, Italy) for the study of AIDS.

\section{References}

1. Fauci, A.S. 1993. Multifactorial nature of human immunodeficiency virus disease: implications for therapy. Science (Wash. DC) .262:1011-1018.

2. Embretson, J., M. Zupancic, J.L. Ribas, A. Burke, P. Racz, K. TennerRacz, and A.T. Haase. 1993. Massive covert infection of helper T lymphocytes and macrophages by HIV during the incubation period of AIDS. Nature (Lond.). 362:359-362.

3. Groux, H., G. Torpier, D. Monté, Y. Mouton, A. Capron, and J.C. Ameisen. 1992. Activation-induced death by apoptosis in $\mathrm{CD}^{+} \mathrm{T}$ cells from human immunodeficiency virus-infected asymptomatic individuals. J. Exp. Med. 175:331-340.

4. Miedema, F., A. Petit, F. Terpstra, J. Eeftinck Schattenkerk, F. DeWolf, B. Al., M. Roos, J. Lange, S. Danner, J. Goudsmit, and P. Schellekens. 1988. Immunological abnormalities in human immunodeficiency virus (HIV)-infected asymptomatic homosexual men: HIV affects the immune system before CD4+ T helper cell depletion occurs. J. Clin. Invest. 82:1908-1914.

5. Shearer, G.M., and M. Clerici. 1991. Early T-helper cell defects in HIV infection. AIDS (Phila.). 5:245-253.

6. Chou, C.C., V. Gudeman, S. O'Rourke, V. Isacescu, R. Detels, G.J. Williams, R.T. Mitsuyasu, and J.V. Giorgi. 1994. Phenotypically defined memory $\mathrm{CD}^{+}{ }^{+}$cells are not selectively decreased in chronic HIV disease. J. Acquired. Immune. Defic. Syndr. 7:665-675.

7. Roederer, M., J.G. Dubs, M.T. Anderson, P.A. Raju, L.A. Herzenberg, and L.A. Herzenberg. 1995. CD8 naive T cell counts decrease progressively in HIV-infected adults. J. Clin. Invest. 95:2061-2066.

8. Mackall, C.L., L. Granger, M.A. Sheard, R. Cepeda, and R.E. Gress. 1993. T-cell regeneration after bone marrow transplantation: differential CD45 isoform expression on thymic-derived versus thymic-independent progeny. Blood. 82:2585-2594.

9. Mackall, C.L., T.A. Fleisher, M.R. Brown, M.P. Andrich, C.C. Chen, I.M Feuerstein, M.E. Horowitz, I.T. Magrath, A.T. Shad, S.M. Steinberg, et al. 1995. Age, thymopoiesis, and $\mathrm{CD}^{+}{ }^{+}$-lymphocyte regeneration after intensive chemotherapy. New Engl. J. Med. 332:143-149.

10. Wain-Hobson, S. 1995. AIDS: Virological mayhem. Nature (Lond.). 373:102.

11. Wei, X., S.K. Ghosh, M.E. Taylor, V.A. Johnson, E.A. Emini, P. Deutsch, J.D. Lifson, S. Bonhoeffer, M.A. Nowak, B.H. Hahn, et al. 1995. Viral dynamics in human immunodeficiency virus type 1 infection. Nature (Lond.). 373:118-122.

12. Ho, D.D., A.U. Neumann, A.S. Perelson, W. Chen, J.M. Leonard, and M. Markowitz. 1995. Rapid turnover of plasma virions and CD4 lymphocytes in HIV-1 infection. Nature (Lond.). 373:123-126.

13. Sprent, J., and D. Tough. 1995. CD4 ${ }^{+}$cell turnover. Nature (Lond.). 375:194.

14. Albertini, R.J., J.A. Nicklas, J.P. O'Neill, and S.H. Robison. 1990. In vivo somatic mutations in humans: measurement and analysis. Annu. Rev. Genet. 24:305-326.

15. Green, M.H.L., J.P. O'Neill, and J. Cole. 1995. Suggestions concerning the relationship between mutant frequency and mutation rate at the hprt locus in human peripheral T-lymphocytes. Mutat. Res. 334:323-339.

16. Hakoda, M., Y. Hirai, M. Akiyama, H. Yamanaka, C. Terai, N. Kamatani, and S. Kashiwazaki. 1995. Selection against blood cells deficient in hypoxanthine phosphoribosyltransferase (HPRT) in Lesch-Nyhan heterozygotes occurs at the level of multipotent stem cells. Hum. Genet. 96:674-680.

17. Gmelig-Meyling, F., S. Dawisha, and A.D. Steinberg. 1992. Assessment of in vivo frequency of mutated $\mathrm{T}$ cells in patients with systemic lupus erythematosus. J. Exp. Med. 175:297-300.

18. Allegretta, M., J.A. Nicklas, S. Sriram, and R.J. Albertini. 1990. T cells responsive to myelin basic protein in patients with multiple sclerosis. Science (Wash. DC). 247:718-721.

19. Centers For Disease Control And Prevention. 1993. Revised classification system for HIV infection and expanded surveillance of definition for AIDS among adolescents and adults. Morbidity Mortality Weekly Reports. 41:1-19.

20. Moretta, A., G. Pantaleo, L. Moretta, M.C. Mingari, and J.C. Cerottini. 1983. Direct demonstration of the clonogenic potential of every human peripheral blood T cells. Clonal analysis of HLA-DR expression and cytolytic activity. J. Exp. Med. 157:743-752.

21. Manetti, R., F. Gerosa, M.G. Giudizi, R. Biagiotti, P. Parronchi, M. Piccinni, S. Sampognaro, E. Maggi, S. Romagnani, and G. Trinchieri. 1994. Interleukin-12 induces stable priming for interferon- $\gamma$ (IFN- $\gamma$ ) production during differentiation of human T helper (Th) cells and transient IFN- $\gamma$ production in established Th2 cell clones. J. Exp. Med. 179:1273-1283.

22. Chen, W.F., A. Wilson, R. Scollay, and K. Shortman. 1982. Limit-dilution assay and clonal expansion of all $\mathrm{T}$ cells capable of proliferation. J. Immunol. Methods. 52:307-322.

23. Cole, J., and T.R. Skopek. 1994. Somatic mutant frequency, mutation rates and mutational spectra in the human population in vivo. Mutat. Res. 304: 33-105.

24. Murphy, M., R. Loudon, M. Kobayashi, and G. Trinchieri. 1986. Gamma interferon and lymphotoxin, released by activated $\mathrm{T}$ cells, synergize to inhibit granulocyte-monocyte colony formation. J. Exp. Med. 164:263-279.

25. van der Pouw-Kraan, T., R. de Jong, and L. Aarden. 1993. Development of human Th1 and Th2 cytokine responses: the cytokine production profile of $\mathrm{T}$ cells is dictated by the primary in vitro stimulus. Eur. J. Immunol. 23:1-5.

26. Maggi, E., M. Mazzetti, A. Ravina, F. Annunziato, M. De Carli, M.P. Piccinni, R. Manetti, M. Carbonari, A.M. Pesce, G. Del Prete, and S. Romagnani. 1994. Ability of HIV to promote a Th1 to Th0 shift and to replicate preferentially in Th2 and Th0 cells. Science (Wash. DC). 265:244-248.

27. Itescu, S., J. Dalton, H. Zhang, and R. Winchester. 1993. Tissue infiltration in a CD8 lymphocytosis syndrome associated with human immunodeficiency virus-1 infection has the phenotypic appearance of an antigenically driven response. J. Clin. Invest. 91:2216-2225. 